Article

\title{
Life Cycle Assessment of an Office Building Based on Site-Specific Data
}

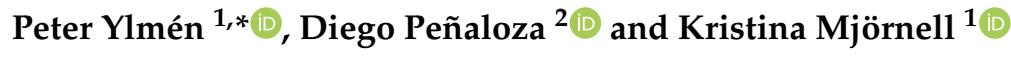 \\ 1 RISE Research Institutes of Sweden, 50115 Borås, Sweden \\ 2 IVL Swedish Environmental Research Institute, 40014 Gothenburg, Sweden \\ * Correspondence: peter.ylmen@ri.se
}

Received: 21 May 2019 ; Accepted: 2 July 2019; Published: 4 July 2019

check for updates

\begin{abstract}
Life cycle assessment (LCA) is an established method to assess the various environmental impacts associated with all the stages of a building. The goal of this project was to calculate the environmental releases for a whole office building and investigate the contribution in terms of environmental impact for different parts of the building, as well as the impact from different stages of the life cycle. The construction process was followed up during production and the contractors provided real-time data on the input required in terms of building products, transport, machinery, energy use, etc. The results are presented for five environmental impact categories and, as expected, materials that constitute the main mass of the building and the energy used during operation contribute the largest share of environmental impact. It is usually difficult to evaluate the environmental impact of the materials in technical installations due to the lack of data. However, in this study, the data were provided by the contractors directly involved in the construction and can, therefore, be considered highly reliable. The results show that materials for installations have a significant environmental impact for four of the environmental impact categories studied, which is a noteworthy finding.
\end{abstract}

Keywords: life cycle assessment (LCA); building; office; technical installations; heating, ventilation, and air conditioning (HVAC)

\section{Introduction}

A few decades ago, it became clear that energy use in buildings has a large environmental impact. Recent years have seen major progress in lowering the energy demand of buildings to mitigate this problem. However, an increasing awareness has emerged of the importance of also considering the products and materials in a building during its complete life cycle in order to further reduce the building's environmental impact. A well-established method to evaluate the environmental impact of a building's life cycle is life cycle assessment (LCA).

To move towards truly low-emission buildings, it is essential to look at the entire life cycle of the buildings including raw material sourcing, production, use, maintenance and waste. If only part of the life cycle is considered, there is a risk that the focus to minimise environmental impact is shifted to another part of the life cycle. Likewise, it is important to consider different environmental aspects to avoid sub-optimisation; for example, efforts to minimise carbon emissions could result in negative effects on other environmental aspects. However, one issue with conducting an LCA is that it demands large quantities of data in order to obtain relevant results and draw useful conclusions. This paper presents an LCA that was carried out on an office building. The approach involved gathering reliable building data and assembling specific data for the LCA to obtain results of high accuracy considering the following environmental impact categories: global warming potential (GWP), 
eutrophication potential (EP), acidification potential (AP), stratospheric ozone depletion potential (ODP) and photochemical oxidants creation potential (POCP).

Although several studies are available that assess whole buildings over their entire life cycle, e.g., [1-17], few studies deal with office buildings in particular, especially in the Nordic countries. International LCA studies that investigate whole commercial buildings are [1-5,11,16], of which [1] studied a section of a Danish office that was assumed to represent the complete building. Although many previous studies are ambitious and thorough, the usual approach is to estimate the amount of materials and products based on architectural drawings and to confer with experts. This approach poses a risk of overlooking products and services with a large environmental impact, especially for more complex buildings such as larger offices.

This study was a post-construction study that aimed to determine the major environmental impacts of an office building by letting the involved contractors gather site-specific data on the investigated building to mitigate the risk of omitting important environmental factors of the life cycle. The approach was to perform a case study in which an actual building was closely followed in real time from the design phase until completion, and then the calculation was made on the finished building. This resulted in high-precision data on how the building was constructed, in contrast to assumptions that would have been used if the LCA was performed during the design stage. The studied object was an office building developed by the Swedish company Vasakronan in which seven of the floors were made mainly from concrete and two floors mainly from wood.

\section{Materials and Methods}

\subsection{Goal and Scope}

The goal and scope of the study that is described in this article was to determine the parts of the building that cause the main environmental impact, with a focus on the building's construction and technical installations.

\subsubsection{Functional Unit}

A building is a multi-functional item and many of its functions are in regulated building codes. To minimise environmental impact when constructing a building, it is important to comply with building codes provisions, for example moisture and fire safety. To consider the building code when carrying out the LCA, the functional unit was set to be $1 \mathrm{~m}^{2} \mathrm{~A}_{\text {temp }}$ which complies with the current Swedish building regulations for a 50 year service life. $A_{\text {temp }}$ is a measurement of floor area intended to be heated to at least 10 degrees Celsius excluding outer walls. The time frame of 50 years was chosen since it is a commonly expected service life for buildings in Sweden.

\subsubsection{System Boundary}

The system boundary for the study was based on the modular approach described in standard EN 15804 [18]. It was not feasible to include all modules in the study due to lack of data. Although efforts were made to fill the data gaps, the project did not have enough resources to gather the necessary data for all modules. The modules that were included in the study were A1-A5, B4, B6 and C1-C4, which are described in [18].

\subsubsection{Environmental Impact Categories}

The mandatory impact categories in EN 15804, and therefore included in this study, are: global warming potential (GWP), eutrophication potential (EP), acidification potential (AP), stratospheric ozone depletion potential (ODP) and photochemical oxidants creation potential (POCP). 


\subsubsection{Data Collection}

Data on building products, energy and waste amounts were provided by the contractors. The data contained information about the products, including their amounts, technical specifications, service life, spillage and maintenance instructions. Data gaps and complementary product information were found in the following sources:

- Environmental product declaration (EPD) of the specific product or, if missing, a similar product.

- Byggvarubedömningen [19], a Swedish tool for evaluating building product contents with regard to environmental aspects. It was used to find raw materials and content for built-in products.

- Building declarations containing information about product content and production energy. To calculate production energy when that information not available from other sources, the Ecoinvent database version 3.2 (allocation, cut-off by classification) [20] for similar products was used.

- Product safety data sheets containing information about product density.

- Product information data sheets that often contain the mass per given unit (pcs, $\mathrm{m}^{2}, \mathrm{~m}$, etc.).

\subsection{Life Cycle Inventory Calculation}

The same nomenclature as in EN 15804 is used to describe the building life cycle. Data calculated for each module is described in Table 1.

Table 1. Calculated data for each life cycle module.

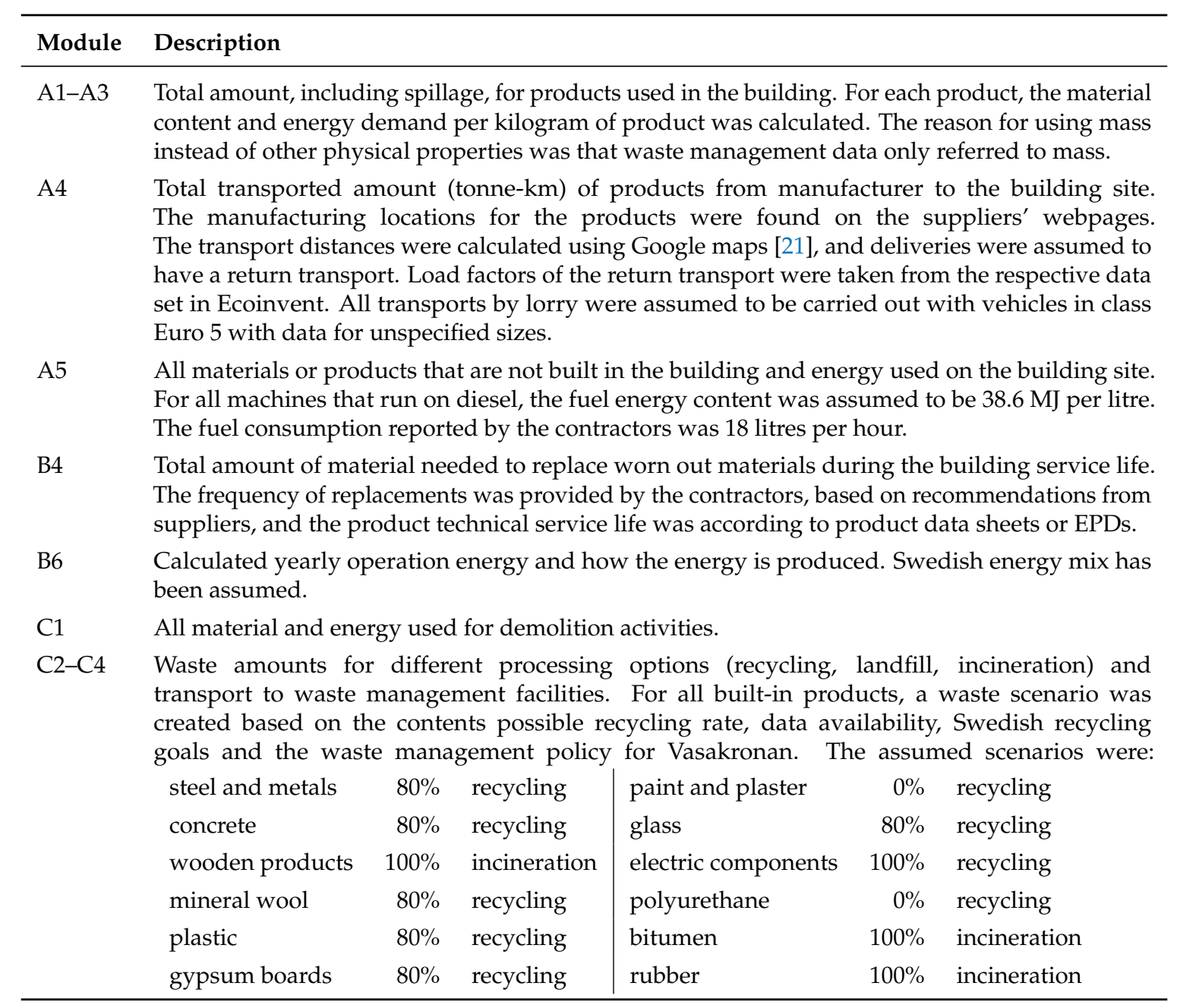




\subsection{Calculation of Environmental Impact}

The data from the life cycle inventory was used to calculate the environmental impact for each module in the building life cycle phase. The environmental impact per kilogram of each product was taken from EPDs when a suitable EPD was available. If there was no suitable EPD or data from Ecoinvent, data from the International Life Cycle Data system (ILCD) [22] was used instead. Data from databases such as Ecoinvent or ILCD are not always representative for Swedish conditions. Therefore, new data sets adapted to Swedish conditions were created for products with a large impact on the results but without suitable EPDs. Examples of such materials are steel, galvanized steel and aluminium. The data sets were based on generic data with adaptions to better represent Swedish industry. Typical adjustments utilised Swedish electricity mix, heat from bio-fuels or Swedish district heating and an increased share of recycled raw materials. The inventory data and calculations are described in more detail in the Supplementary File.

\subsection{Sensitivity Analysis}

The energy mix for the operational life cycle stage, as well as manufacturing of copper and aluminium parts for the production and maintenance stages, have large uncertainties that can influence the results. A sensitivity analysis was carried out in order to evaluate the effect from these parameters, more specifically the choice of upstream data for the LCA model. The data for the electricity mix was changed from average electricity consumer mix for Sweden to the residual mix and electricity from hydropower. Additionally, the data for aluminium and copper production was changed from Ecoinvent data to data from Thinkstep database in Gabi 8.

\section{Results}

A total of 529 different products were in the list of built-in products provided by the contractors. The products consisted of 220 different types of raw materials. The distribution of material categories is shown in Figure 1. The building mass was mainly concrete (46\%), gravel and crushed stone (30\%) and steel materials $(15 \%)$, which together constitute $96 \%$ of the building's total mass.

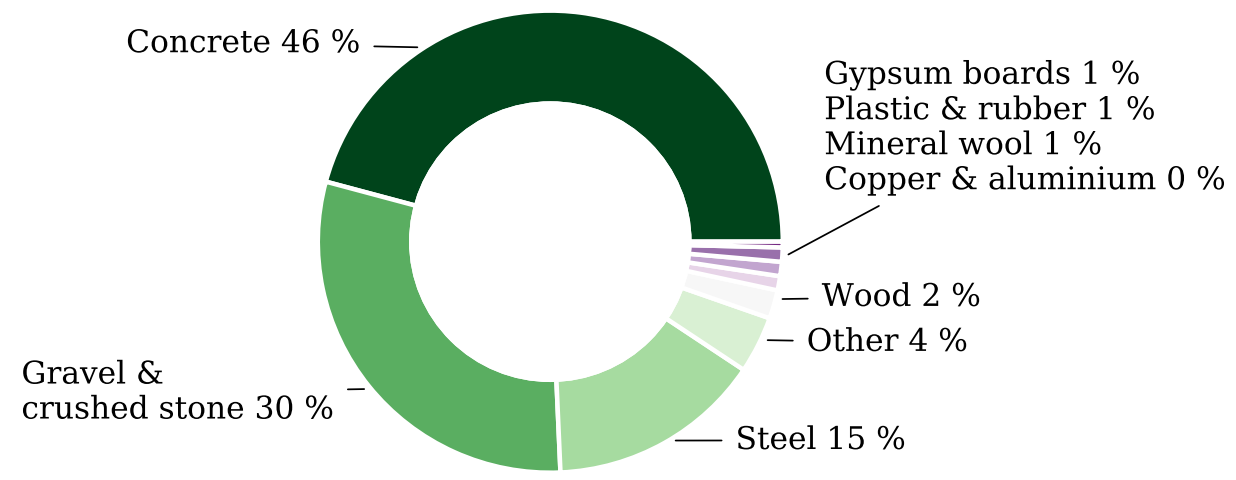

Figure 1. Distribution of mass for different material categories in the building.

Normalised results for the whole building are presented in Figure 2. In each category, the production of building products (A1-A3) and operation (B4, B6) are the life cycle phases with the dominant impacts. Regarding EP, AP and ODP, the building's operation is the largest contributor, while material production is the phase with the largest impact for GWP and POCP. Transport (A4), assembly (A5) and demolition (C1) have negligible environmental impact on the results according to this study. Waste management (C2-C4) has small yet significant (2-6\%) impact in all environmental impact categories considered. 


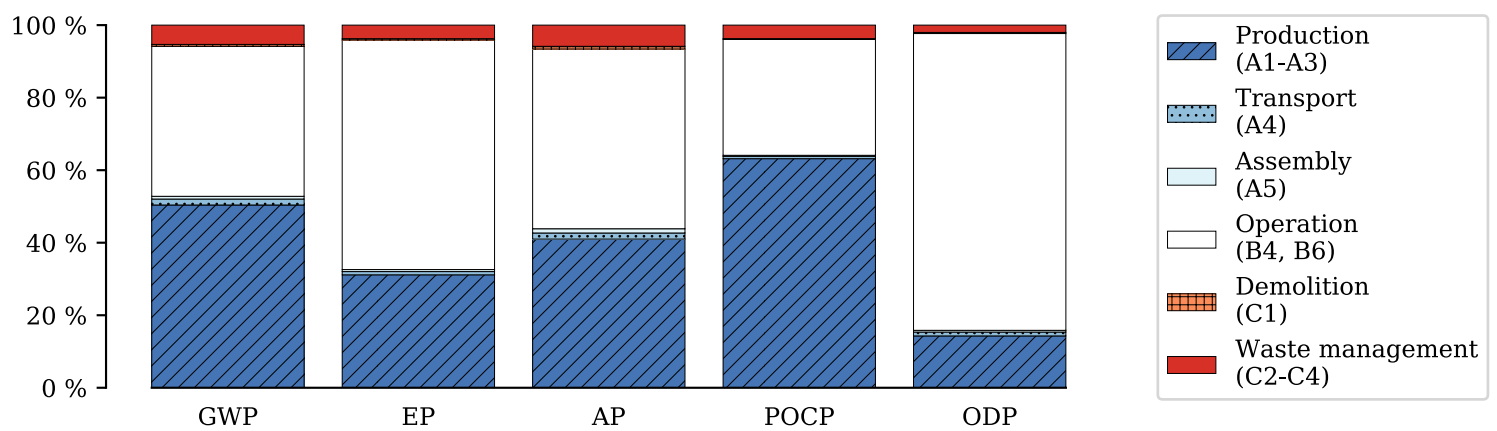

Figure 2. Normalised results for the whole building for each of the impact categories investigated.

The environmental impact from the operation energy in the use phase (B6) is $16-74 \%$ for the investigated environmental impact categories, which is a common result for traditional studies of buildings. Since the focus of the research project was building materials, the energy use will not be further discussed in this article. Instead, the focus will be on results regarding the contribution from materials and environmental aspects related to material choices.

Figure 3 shows the results for the environmental impact of the whole building. For GWP, the life cycle phase with the largest emissions, besides energy use during operation (B6), is the manufacture of building products (A1-A3), mainly due to the building framework and inside construction parts. The manufacture of steel and concrete products contributes a large share of the total GWP. Only galvanized steel profiles account for approximately $32 \%$, while concrete casted on site and prefabricated concrete elements amount to roughly $20 \%$ of the impact. Other significant contributors are mineral wool in ceilings (4\%) and polystyrene ground insulation (5\%). The replacement (B4) of parts in the heating, ventilation and air conditioning (HVAC) system, mainly due to stainless steel and aluminium parts, as well as mineral wool boards mounted in places other than ceilings, also have a relevant impact.

The results for EP and AP show less importance of the concrete framework in production (A1-A3) than for GWP. The dominant processes concerning EP and AP are the production (A1-A3) and replacement (B4) of copper pipes and other HVAC components. Concrete cast on site, prefabricated concrete elements, steel parts and mineral wool boards have a large impact for AP as well, but less effect on EP. One explanation for these differences is the greater effect of galvanized steel profiles and mineral wool boards on AP.

The results for the impact categories POCP and ODP show that POCP is mainly affected by the production of the construction materials and products (A1-A3), especially the concrete framework in this case, mainly due to its content of expanded polystyrene (EPS) insulation. ODP, on the other hand, is heavily affected by the energy use during operation of the building and has less impact from the material and building products compared to the other environmental impact categories investigated.

\subsection{Sensitivity Analysis Results}

The results from the sensitivity analysis, presented in Figure 4, show that changes to electricity mix and production of copper and aluminium have a small effect in GWP and EP. The most prominent change is that $\mathrm{EP}$ for energy use decreases to 0.4 ( $\mathrm{kg} \mathrm{PO}_{4}^{3-}$ eq.)/f.u. With regard to $\mathrm{AP}, \mathrm{POCP}$ and ODP the most drastic change is that the impact for HVAC increases more than five times, while the impact of the category energy use is less affected. This in turn leads to a change in the relative impact of production (A1-A3) in these environmental categories, as can be seen in Figure 5. 

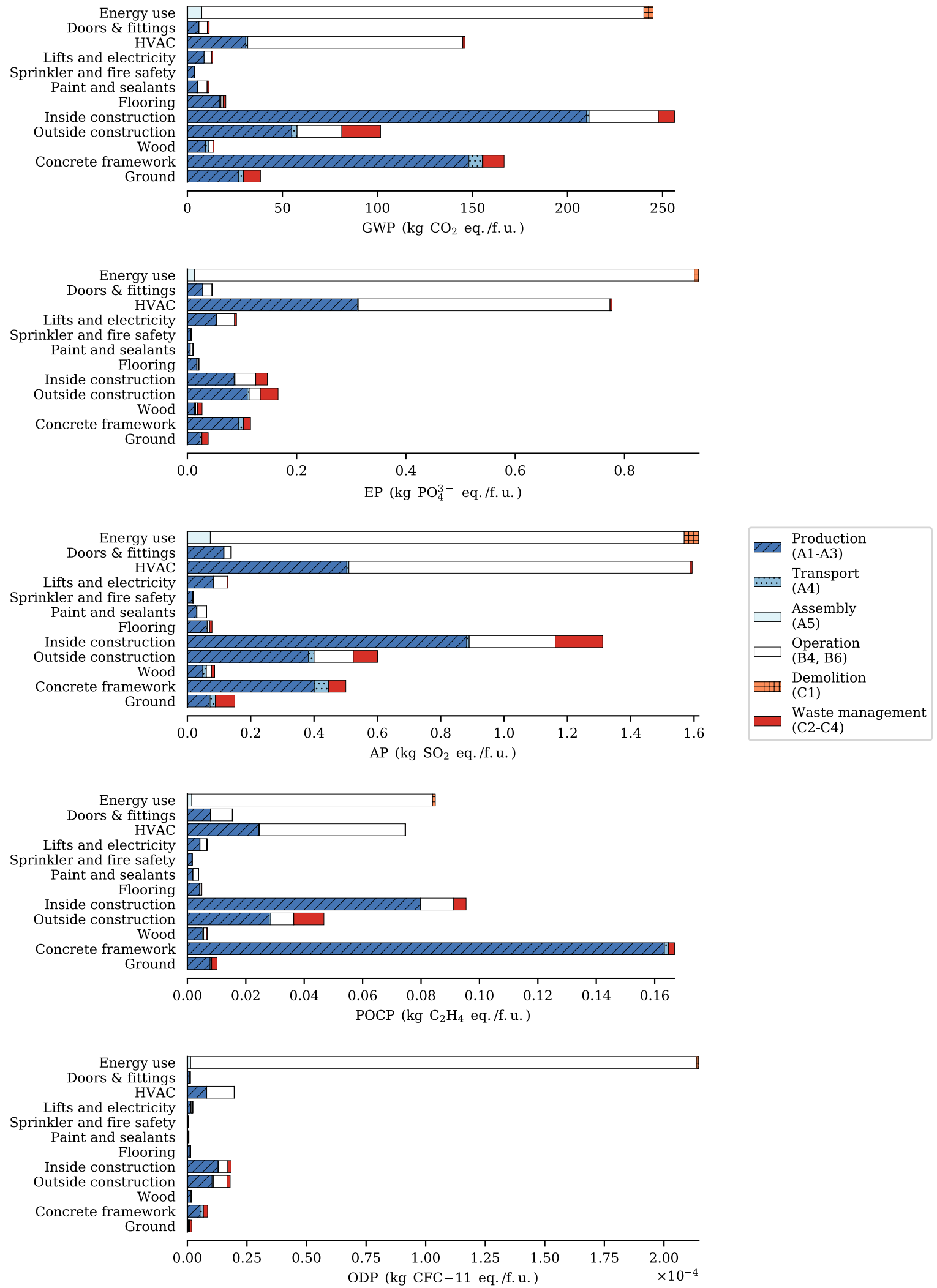

Figure 3. Impact of the different parts in the building for the environmental impact categories investigated. 

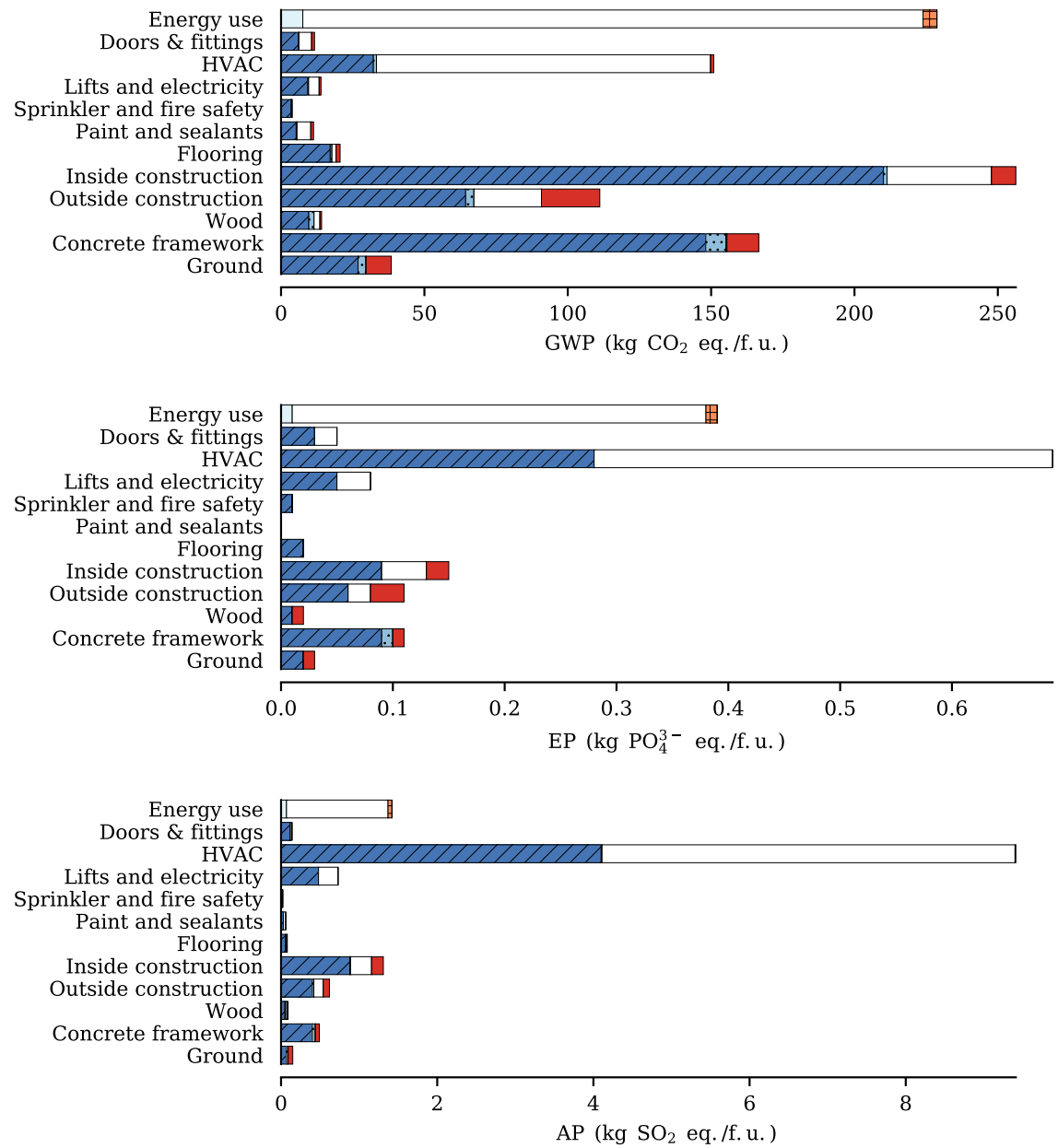

\begin{tabular}{|c|c|}
\hline$\nabla / 7$ & $\begin{array}{l}\text { Production } \\
\text { (A1-A3) }\end{array}$ \\
\hline$\ldots \ldots$ & $\begin{array}{l}\text { Transport } \\
\text { (A4) }\end{array}$ \\
\hline$\square$ & $\begin{array}{l}\text { Assembly } \\
\text { (A5) }\end{array}$ \\
\hline & $\begin{array}{l}\text { Operation } \\
(\mathrm{B} 4, \mathrm{~B} 6)\end{array}$ \\
\hline 四曲 & $\begin{array}{l}\text { Demolition } \\
\text { (C1) }\end{array}$ \\
\hline & $\begin{array}{l}\text { Waste management } \\
\text { (C2-C4) }\end{array}$ \\
\hline
\end{tabular}
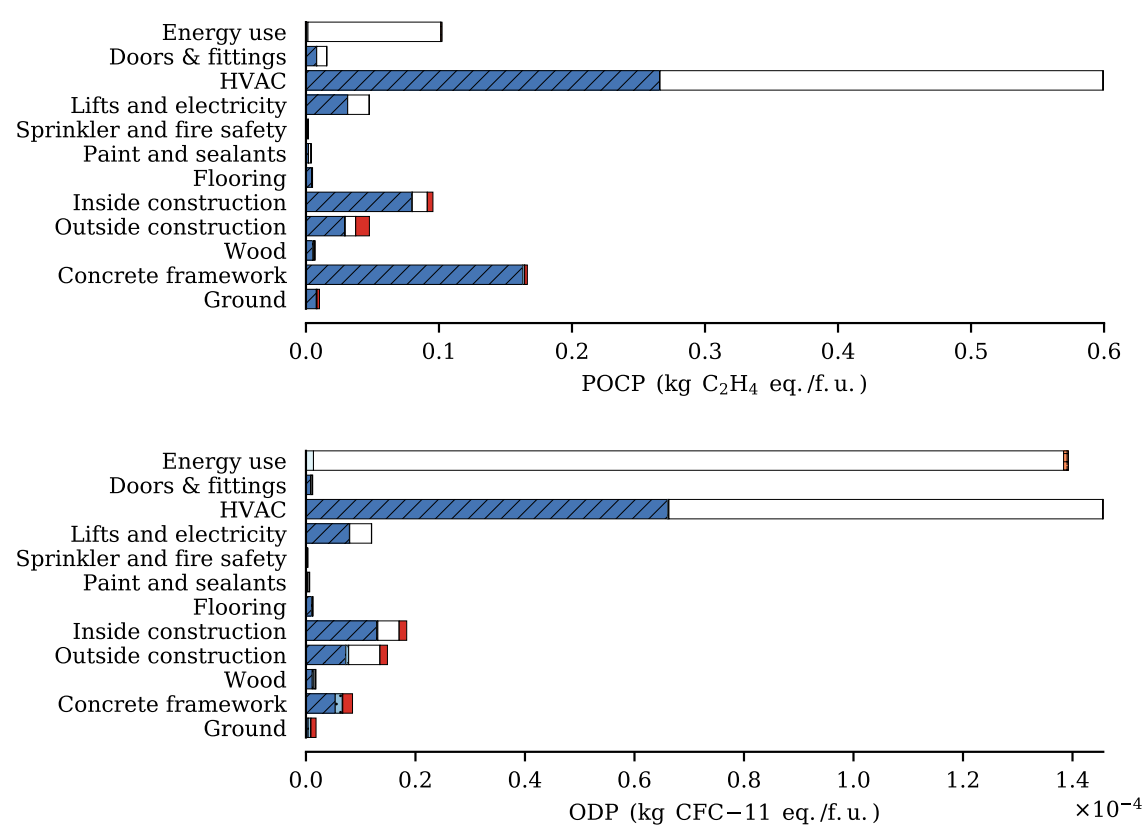

Figure 4. Impact of the different parts in the building for the environmental impact categories investigated, with changed parameters for electricity mix, copper and aluminium. 


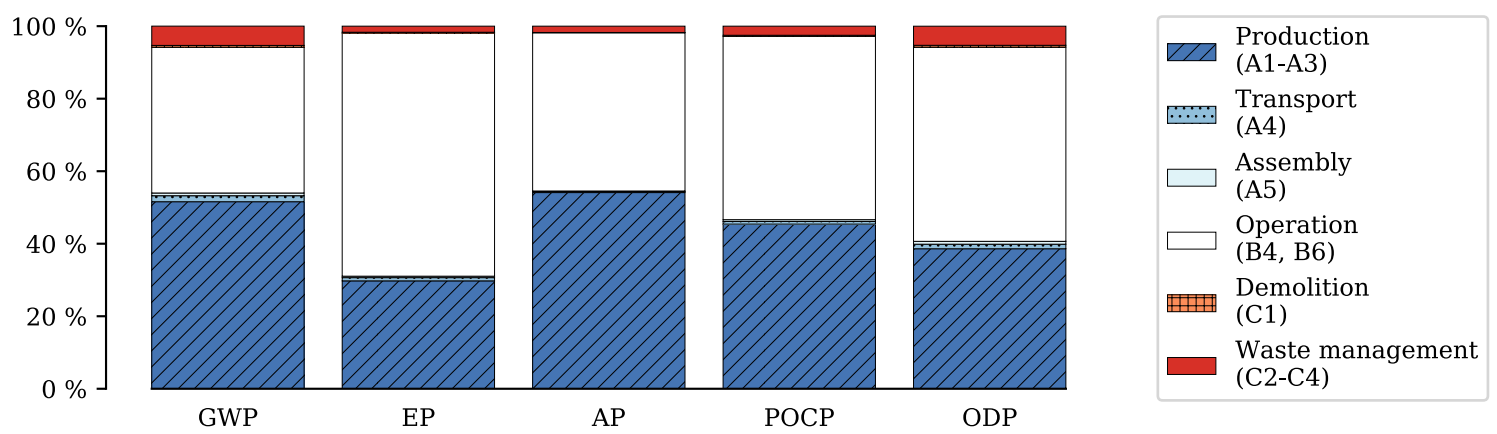

Figure 5. Normalised results for the whole building for each of the impact categories investigated, with changed parameters for electricity mix, copper and aluminium.

\section{Discussion}

The aim of this study was to determine major environmental impacts of an office building by following a real building project from its design phase through to completion. The results and analyses demonstrate both strengths and weaknesses. The main strength of the study is the emphasis on collecting data that is specific to the building project. Data on material amounts, waste at the building site and energy use during production (A1-A5) were provided by the contractors on-site and, therefore, have high credibility. Additionally, product data sheets were provided for most of the products which means that there is also high credibility of the raw material composition and production energy for the products used in the building. A weakness of the study is the unavailability of data on building maintenance due to lack of information. It is likely that these factors would affect the outcome of the study in some way, since they would increase the environmental impact of the operation phase. Another common issue is the impact from end-of-life, since it occurs in the long-term future and therefore entails significant uncertainty. Both these issues require further research.

For GWP the result is mainly affected by steel and concrete elements, which is explained primarily by their large share of mass in the building. The relatively low contribution from transport (A4) in all the impact categories was somewhat unexpected since large parts of the building were prefabricated; however, the relative low impact of transport has also been found in other studies, e.g., [14]. Changed assumptions regarding transport, such as size of vehicles or load factors, were studied but had small effects (less than $5 \%$ ) on the results. However, there are some uncertainties in the calculations. Because there were over one hundred suppliers it was not practically feasible to simulate all the transport trips in detail, especially concerning hidden transport due to subcontracting. It is a possibility that some transport distances were underestimated, although the small contribution from transport in the results suggest that even these uncertainties will not change the conclusions made in this study.

Copper and aluminium in the HVAC-system significantly contribute to the impact categories AP and EP (25\% and $33 \%$, respectively). Copper is a metal with an unstable global market and its impact is highly dependent on its value chain. The impacts on acidification and eutrophication have a strong correlation with the use of fossil fuel during mining and transport to smelters where $\mathrm{NO}_{\mathrm{x}}$ and $\mathrm{SO}_{\mathrm{x}}$ are emitted. Modelling these kinds of activities with high accuracy is challenging due to the large number of products and suppliers for these materials. The results from the sensitivity analysis in Figures 4 and 5 show that the choice of upstream data can significantly influence the outcome of the study. This issue is very common and well-known for the choice of electricity during the building's operation, since different electricity generation technologies have different environmental releases. On the other hand, the choice of data on copper and aluminium brings different results depending on factors such as technology used, location of manufacture, and percentage of recycled metal used in production. The sensitivity analysis explores alternative datasets available containing generic data. These datasets are not necessarily representative of the products used in the building. However, the suppliers of these materials did not provide specific product data for their products, and generic data has to be used as 
a replacement. In order to effectively overcome this uncertainty specific product data is required for copper and aluminium.

The impacts from HVAC-systems are often omitted in the LCA of buildings due to lack of data [6]. In this study, the data on product amounts in the technical installations were provided directly from the contractors and can, therefore, be considered reliable. The considerable contribution from the HVAC-system is therefore a noteworthy finding. The main reason for the large impact is that several parts in the technical installations have to be replaced during the studied timeframe. Omitting the HVAC-system in an LCA of buildings can ignore a considerable part of the environmental impact for several impact categories. The finding that the replacement of some products (B4) accounts for a major part of the impact of some products should also be pointed out. The industrial partners in the project were unable to provide information on replacement, since this is usually not planned but done on an ad-hoc basis. The service lives of the parts were instead estimated from the technical service life provided by the suppliers. To improve the accuracy of the data for replacements in the future, it would be beneficial to collect statistics from the operational management of similar buildings.

As can be seen in Figure 3, relative magnitudes in environmental impact between the parts of the building vary depending on which environmental impact category that is considered. For example, the concrete framework has the largest environmental impact for POCP but is only the fifth largest impact regarding AP. Similar differences in magnitude can also be noted for other parts of the building. This implies that the correlation between different impact categories can be low. However, Figure 3 also shows that some parts, e.g., sprinkler and fire safety, have a low impact in all environmental categories investigated. This will also depend on how the building is divided into different groups. If all groups except energy use were grouped as a single category, this group would of course have a larger environmental impact compared to energy use.

It is difficult to compare studies involving LCAs on buildings since they target different buildings, functional units, system boundaries and method choices [9]. Previous studies that analyse a whole buildings during the full life cycle and present the impact share of the different building parts are $[1,2,6,8-11,14]$. These also shows that energy use (B6) and production (A1-A3) represent a large share of the total environmental impact, similar to our results. In contrast, the studies do report a lower impact share of the installations than was presented in this article. For studies of residential buildings, a likely explanation is that there are commonly fewer installations in these types of buildings than for commercial buildings. However, [1,2] have similar building types, office with concrete frame, but also report smaller shares of environmental impact from the technical installations. It is possible that these differences are caused by missing products in the inventory of these studies, but there are also other possible explanations: the buildings have less technical installations, the functional unit is different or that the purpose and therefore method choices are different. The latter reason is indicated in [1], since the focus in that study was difference of several construction alternatives and only steel, iron, PVC and ceramics are reported for technical installations. In our study it was found that other materials in the technical installations, e.g. copper and aluminium, have significant (64-93\%) environmental impact in the HVAC-system.

This study provides information on the environmental impacts associated with the life cycle of an office building. The presented results provide insights into the magnitude of environmental impact for the parts of the building during the different phases of its life cycle. This will make it easier in the future to prioritise measures when designing buildings with higher environmental performance.

\section{Conclusions}

The results from the study show the environmental impact from parts of the building for different phases in its life cycle. In each environmental category investigated, the production of building products, operation energy and replacement are the life cycle phases with the largest impacts. Waste management has small but yet significant impact (2-6\%) in all environmental impact categories, while transport, assembly and demolition have little environmental impact on the results according to 
this study. The importance of energy use and production was expected, as has also been shown in other studies. A novel finding was the significant impact (14-32\%) of the technical installations in four out of five environmental impact categories, for which earlier studies of buildings often disregarded due to lack of data. This finding highlights the importance of these kinds of products in the environmental impact mitigation of buildings. Investigating all the transport trips to the building site was complex, but the results show that transport has a small effect on the total environmental impact of the building.

Supplementary Materials: The following are available online at http:/ / www.mdpi.com/1996-1073/12/13/2588/ s1,

Author Contributions: The authors individual contributions to this work are: methodology D.P. and P.Y.; investigation, D.P. and P.Y.; writing-original draft preparation, P.Y.; writing-review and editing, K.M. and D.P.; visualization, P.Y.; supervision, K.M.; project administration, P.Y.; funding acquisition, P.Y., D.P. and K.M.

Funding: We would like to thank BioInnovation, The Swedish Innovation Agency (Vinnova), The Swedish Energy Agency and Vasakronan for funding of the research project and the construction industry's organisation for research and development (SBUF) for their financial contribution to the making of this article.

Acknowledgments: This article describes part of a recent research project regarding LCA of the investigated building. More information about the project can be found in the report [23]. We would like to acknowledge Peab for their work with collecting and compile information from the building project.

Conflicts of Interest: Vasakronan has been involved in the formulation of research question and assisted in the process of collecting data. The funders had no role in analyses, or interpretation of data; in the writing of the manuscript, or in the decision to publish the results.

\section{References}

1. Eberhardt, L.C.M.; Birgisdóttir, H.; Birkved, M. Life cycle assessment of a Danish office building designed for disassembly. Build. Res. Inf. 2019, 47, 666-680, doi:10.1080/09613218.2018.1517458. [CrossRef]

2. Junnila, S. The Environmental Impact of an Office Building Throughout Its Life Cycle. Ph.D. Thesis, Helsinki University of Technology, Construction Economics and Management, Espoo, Finland, 2004.

3. Georges, L.; Haase, M.; Houlihan Wiberg, A.; Kristjansdottir, T.; Risholt, B. Life cycle emissions analysis of two nZEB concepts. Build. Res. Inf. 2015, 43, 82-93, doi:10.1080/09613218.2015.955755. [CrossRef]

4. Wallhagen, M.; Glaumann, M.; Malmqvist, T. Basic building life cycle calculations to decrease contribution to climate change-Case study on an office building in Sweden. Build. Environ. 2011, 46, 1863-1871, doi:10.1016/j.buildenv.2011.02.003. [CrossRef]

5. Wiik, M.K.; Fufa, S.M.; Kristjansdottir, T.; Andresen, I. Lessons learnt from embodied GHG emission calculations in zero emission buildings (ZEBs) from the Norwegian ZEB research centre. Energy Build. 2018, 165, 25-34, doi:10.1016/j.enbuild.2018.01.025. [CrossRef]

6. Larsson, M.; Erlandsson, M.; Malmqvist, T.; Kellner, J. Byggandets Klimatpåverkan. Livscykelberäkning Av Klimatpåverkan För ett Nyproducerat Flerbostadshus Med Massiv Stomme Av Trä. Report 1652-5442 (ISSN). 2016. Available online: https:/ / www.ivl.se/download/18.29aef808155c0d7f05063/1467900250997/ B2260.pdf (accessed on 17 April 2019).

7. Hong, J.; Shen, G.Q.; Feng, Y.; Lau, W.S.t.; Mao, C. Greenhouse gas emissions during the construction phase of a building: A case study in China. J. Clean. Prod. 2015, 103, 249-259, doi:10.1016/j.jclepro.2014.11.023. [CrossRef]

8. Pajchrowski, G.; Noskowiak, A.; Lewandowska, A.; Strykowski, W. Materials composition or energy characteristic-What is more important in environmental life cycle of buildings? Build. Environ. 2014, 72, 15-27, doi:10.1016/j.buildenv.2013.10.012. [CrossRef]

9. Liljenström, C.; Malmqvist, T.; Erlandsson, M.; Fredén, J.; Adolfsson, I.; Larsson, G.; Brogren, M. Byggandets Klimatpåverkan: Livscykelberäkning av Klimatpåverkan och Energianvändning för ett Nyproducerat Energieffektivt Flerbostadshus i Betong; Report 978-91-7595-218-5 (ISBN); Sveriges Byggindustrier: Stockholm, Sweden, 2015. Available online: http:/ / urn.kb.se/resolve?urn=urn:nbn:se:kth:diva-147209 (accessed on 17 April 2019).

10. Proietti, S.; Sdringola, P.; Desideri, U.; Zepparelli, F.; Masciarelli, F.; Castellani, F. Life Cycle Assessment of a passive house in a seismic temperate zone. Energy Build. 2013, 64, 463-472, doi:10.1016/j.enbuild.2013.05.013. [CrossRef] 
11. Asdrubali, F.; Baldassarri, C.; Fthenakis, V. Life cycle analysis in the construction sector: Guiding the optimization of conventional Italian buildings. Energy Build. 2013, 64, 73-89, doi:10.1016/j.enbuild.2013.04.018. [CrossRef]

12. Dahlstrøm, O.; Sørnes, K.; Eriksen, S.T.; Hertwich, E.G. Life cycle assessment of a single-family residence built to either conventional- or passive house standard. Energy Build. 2012, 54, 470-479, doi:10.1016/j.enbuild.2012.07.029. [CrossRef]

13. Cuellar-Franca, R.M.; Azapagic, A. Environmental impacts of the UK residential sector: Life cycle assessment of houses. Build. Environ. 2012, 54, 86-99, doi:10.1016/j.buildenv.2012.02.005. [CrossRef]

14. Blengini, G.A.; Di Carlo, T. The changing role of life cycle phases, subsystems and materials in the LCA of low energy buildings. Energy Build. 2010, 42, 869-880, doi:10.1016/j.enbuild.2009.12.009. [CrossRef]

15. Citherlet, S.; Defaux, T. Energy and environmental comparison of three variants of a family house during its whole life span. Build. Environ. 2007, 42, 591-598, doi:10.1016/j.buildenv.2005.09.025. [CrossRef]

16. Scheuer, C.; Keoleian, G.A.; Reppe, P. Life cycle energy and environmental performance of a new university building: modeling challenges and design implications. Energy Build. 2003, 35, 1049-1064. [CrossRef]

17. Adalberth, K. Energy use during the life cycle of buildings: a method. Build. Environ. 1997, 32, 317-320, doi:10.1016/S0360-1323(96)00068-6. [CrossRef]

18. SIS/TK 209. SS-EN 15804:2012-Sustainability of Construction Works-Environmental Product Declarations-Core Rules for the Product Category of Construction Products; Swedish Institute for Standards: Stockholm, Sweden, 2012.

19. Byggvarubedömningen. Available online: https://byggvarubedomningen.se/in-english/ (accessed on 17 April 2019).

20. Ecoinvent Centre. Available online: http://www.ecoinvent.org/database/database.html (accessed on 17 April 2019).

21. Google Maps. Available online: https://www.google.com/maps/ (accessed on 17 April 2019).

22. ILCD International Life Cycle Data System. Available online: https://eplca.jrc.ec.europa.eu/ilcd.html (accessed on 17 April 2019).

23. Ylmen, P.; Peñaloza, D.; Schade, J. Livscykelstudie av Kontor Med Kombinerad Betong- Och TräKonstruktion. Report 978-91-88907-26-4 (ISBN). 2018. Available online: http://urn.kb.se/resolve?urn=urn:nbn:se:ri: diva-36669 (accessed on 17 April 2019).

(C) 2019 by the authors. Licensee MDPI, Basel, Switzerland. This article is an open access article distributed under the terms and conditions of the Creative Commons Attribution (CC BY) license (http://creativecommons.org/licenses/by/4.0/). 